\title{
Limitations of microbial hydrocarbon degradation at the Amon mud volcano (Nile deep-sea fan)
}

\author{
J. Felden ${ }^{1,2}$, A. Lichtschlag ${ }^{3, *}$, F. Wenzhöfer ${ }^{1,2}$, D. de Beer ${ }^{3}$, T. Feseker ${ }^{2}$, P. Pop Ristova ${ }^{1,2}$, G. de Lange ${ }^{4}$, and \\ A. Boetius ${ }^{1,2}$ \\ ${ }^{1}$ Helmholtz - Max Planck Research Group for Deep Sea Ecology and Technology, Alfred Wegener Institute Helmholtz \\ Center for Polar and Marine Research and Max Planck Institute for Marine Microbiology, Bremen, Germany \\ ${ }^{2}$ MARUM Center for Marine Environmental Sciences, University Bremen, Germany \\ ${ }^{3}$ Max Planck Institute for Marine Microbiology, Bremen, Germany \\ ${ }^{4}$ Geosciences, Utrecht University, Utrecht, the Netherlands \\ * present address: National Oceanography Centre, University of Southampton Waterfront Campus, Southampton, UK
}

Correspondence to: J. Felden (jfelden@marum.de)

Received: 13 November 2012 - Published in Biogeosciences Discuss.: 8 January 2013

Revised: 29 March 2013 - Accepted: 19 April 2013 - Published: 14 May 2013

\begin{abstract}
The Amon mud volcano (MV), located at $1250 \mathrm{~m}$ water depth on the Nile deep-sea fan, is known for its active emission of methane and non-methane hydrocarbons into the hydrosphere. Previous investigations showed a low efficiency of hydrocarbon-degrading anaerobic microbial communities inhabiting the Amon MV center in the presence of sulfate and hydrocarbons in the seeping subsurface fluids. By comparing spatial and temporal patterns of in situ biogeochemical fluxes, temperature gradients, pore water composition, and microbial activities over $3 \mathrm{yr}$, we investigated why the activity of anaerobic hydrocarbon degraders can be low despite high energy supplies. We found that the central dome of the Amon MV, as well as a lateral mud flow at its base, showed signs of recent exposure of hot subsurface muds lacking active hydrocarbon degrading communities. In these highly disturbed areas, anaerobic degradation of methane was less than $2 \%$ of the methane flux. Rather high oxygen consumption rates compared to low sulfide production suggest a faster development of more rapidly growing aerobic hydrocarbon degraders in highly disturbed areas. In contrast, the more stabilized muds surrounding the central gas and fluid conduits hosted active anaerobic hydrocarbon-degrading microbial communities. The low microbial activity in the hydrocarbonvented areas of Amon MV is thus a consequence of kinetic limitations by heat and mud expulsion, whereas most of the outer MV area is limited by hydrocarbon transport.
\end{abstract}

\section{Introduction}

Submarine mud volcanoes (MV) form where tectonic or gravitational forces induce vigorous discharge of muds, fluids and methane gas from deep subsurface strata (Milkov, 2000; Kopf, 2002). Long-term degassing after eruption events via subsurface conduits can promote the formation of cold-seep ecosystems at the seafloor, attracting diverse and rich chemosynthetic communities (Sibuet and Olu, 1998; Werne et al., 2004; Niemann et al., 2006). In most cold-seep ecosystems, the anaerobic oxidation of methane (AOM) with sulfate is a key biogeochemical process, delivering sulfide to fuel chemosynthetic life (Boetius et al., 2000). Sulfide oxidation provides energy to thiotrophic bacteria that are either free living or symbiotically associated with chemosynthetic animals (Jørgensen and Boetius, 2007). Cold seeps emitting higher hydrocarbons and oil in addition to methane generally show the highest sulfate reduction rates and sulfide fluxes, often exceeding AOM (e.g., Joye et al., 2004; Omoregie et al., 2009). AOM occurs where methane and sulfate meet, and decreases methane emission to the hydrosphere across a wide range of environmental conditions (Knittel and Boetius, 2009). Due to the activity of methanotrophic microbial communities, the ocean is a relatively minor source of the greenhouse gas methane (Reeburgh, 2007).

Recently, numerous studies investigated spatial distribution patterns of seep communities and biogeochemical 
processes, indicating that transport of gases and fluids to the surface seafloor are the main factors shaping cold-seep ecosystems (e.g., Sibuet and Olu, 1998; Niemann et al., 2006; Cordes et al., 2010; Grünke et al., 2011; Ritt et al., 2011). Generally, one may expect that higher hydrocarbon flux relates to higher microbial activity as more electron donor becomes available. However, several recent studies have also indicated transport-related limitations to the microbial efficiency in anaerobic consumption of methane: for example, in active MV systems with high upward flow rates of sulfate-depleted subsurface fluids, microbial activity is limited by the lack of electron acceptors (de Beer et al., 2006; Felden et al., 2010). Furthermore, kinetic limitations affecting the function of microbial metabolism may apply for example in highly acidic (Inagaki et al., 2006; Yanagawa et al., 2012), briny (Joye et al., 2009) or hyperthermophilic environments (Brazelton et al., 2006; Holler et al., 2011).

Here we studied biogeochemical processes at the active Amon MV, which is situated on the border between the central and eastern regions of the Nile deep-sea fan and characterized by high thermal gradients (Dupré et al., 2007, 2008, 2010). Deposition of evaporites during the Messinian sealed an underlying petroleum system, which leaks through faults piercing the Messinian evaporites and enriching the ascending fluids in sulfate from gypsum dissolution (Foucher et al., 2009; de Lange and Krijgsman, 2010). The Amon MV has a dome-shaped structure formed by one main feeding channel for the upward transport of muds, fluids, and gases from the deep subsurface. In addition, a lateral outflow of briny muds occurs at its base (Girnth et al., 2011). Earlier investigations showed conspicuously high methane and hydrocarbon emissions into the hydrosphere, and an apparent limitation of anaerobic microbial hydrocarbon degradation in the sediments of the Amon MV, despite the availability of sulfate excluding transport limitation (Mastalerz et al., 2009; Omoregie et al., 2009). Hence, the aim of this study was to investigate potential kinetic limitations of hydrocarbon degradation, and the consequences for the structure and functioning for the cold-seep ecosystem of Amon MV. We tested the following hypotheses: (I) methanotrophic activity is repressed by the composition of subsurface fluids; (II) methane oxidation is absent from hot subsurface mud advected rapidly from greater depth; (III) methanotrophic communities develop too slowly to populate MV sediments disturbed from recent gas eruptions.

\section{Materials and methods}

\subsection{Sampling site}

The Nile deep-sea fan is one of the world's largest deep-sea fans $\left(90000 \mathrm{~km}^{2}\right)$ and comprises large subsurface gas and oil reservoirs (Mascle et al., 2006). The Amon MV (31 $42.6^{\prime} \mathrm{E}$, $\left.32^{\circ} 22.2^{\prime} \mathrm{N}\right)$ is associated with an area of the Egyptian mar- gin subject to rapid subsidence and abundant sedimentation, leading to the burial of thick accumulations of organic-rich sediments and the formation of hydrocarbons (Dolson et al., 2002). It is located at a water depth of about $1120 \mathrm{~m}$, has a diameter of $2 \mathrm{~km}$, and a maximal elevation of $90 \mathrm{~m}$ above the surrounding seafloor (Fig. 1). Previous studies of the Amon MV were based on bathymetric and visual investigations (Mascle et al., 2001; Dupré et al., 2007, 2008, 2010) or focused on the community composition in some selected habitats (Girnth et al., 2011; Grünke et al., 2011; Ritt et al., 2011). The slope of the Amon MV decreases gently from the central mound to the outer edges (Dupré et al., 2007). Sampling and in situ measurements (Supplement Table 1 and PANGAEA database (doi:10.1594/PANGAEA.804779)) were performed at locations indicated in Fig. 1 during the M70-2 Bionil cruise with the RV Meteor (2006) and the MSM13-3 with the RV M.S. Merian (2009). Substantial gas flares were detected above Amon in the ship's, ROV's, and AUV's hydro-acoustic sonar, indicating free gas ebullition (Freiwald et al., 2011; Boetius, 2012). Precise positioning and operation of the in situ tools as well as targeted sampling of the different MV habitats were achieved by using the Posidonia navigation system (POSIDONIA; IXSEA SAS; Marly-le-Roi; France) on the ship, the winch operated tools and the remotely operated vehicle (ROV) QUEST 4000 (Marum, Bremen, Germany). Also, physical markers were deployed at the seafloor for orientation during both expeditions. Based on visual observation and in consistence with micro-bathymetric measurements published previously (Dupré et al., 2007, 2008; Girnth et al., 2011), four habitats can be visually distinguished and were sampled at the Amon MV (Fig. 1): (I) central dome, (II) bacterial mats, (III) biogenic mounds, and (IV) a lateral mud flow at the foot of the Amon MV termed "sulfur band". Additionally, measurements and sampling were performed at a reference site outside of the Amon MV area. At all habitats, the upper $30 \mathrm{~cm}$ of the sediment were sampled with push cores (PCs) operated by the ROV. On board the ship, the PCs were stored and processed at in situ bottom water temperature of $14^{\circ} \mathrm{C}$. Some samples contained high amounts of gas and their retrieval disturbed the sediment stratification by gas ebullition. To re-establish the geochemical gradients, the cores were stored at in situ temperature until the mud settled and bacterial mats recovered. In addition to sampling with PCs, sediments were sampled by gravity coring down to $380 \mathrm{~cm}$ bsf (below seafloor). After recovery, all gravity cores (GCs) were immediately processed.

\subsection{Consumption rates of methane and sulfate}

\subsubsection{Ex situ turnover rates of methane and sulfate}

Rates were determined according to Treude et al. (2003) and references therein, using radioisotope tracer methods for sulfate reduction and anaerobic methane oxidation. For each method and sampling station 3-4 replicate subcores were 

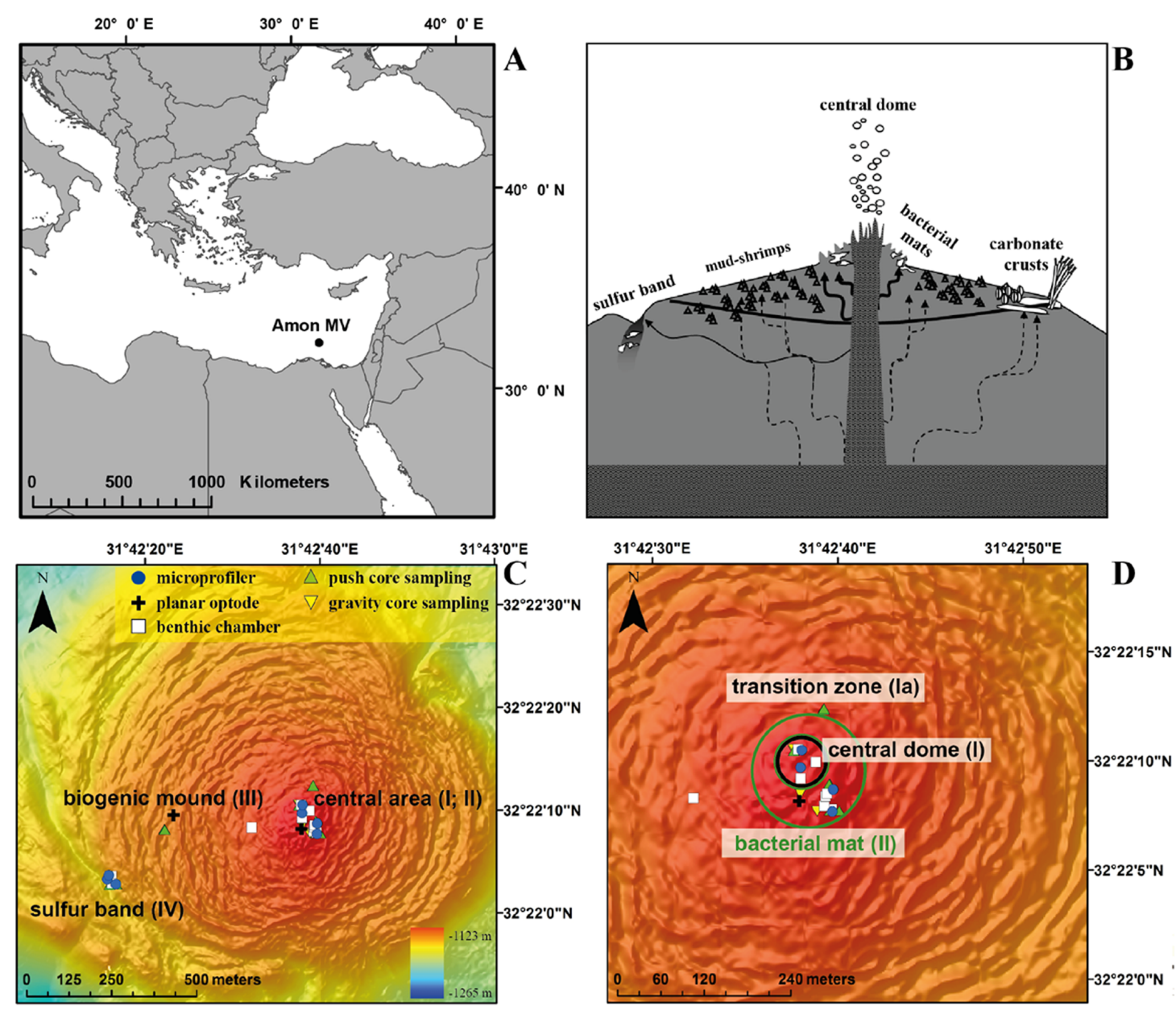

Fig. 1. Sampling sites. (A) The Amon MV is located on the Nile deep-sea fan of the Eastern Mediterranean. (B) Schematic drawing of habitats at the Amon MV. The habitats are not scaled to the same dimensions. (C), (D) Positions of all in situ instrument deployments and push core sampling at the Amon MV in 2006 and 2009. In the central area bacterial mats (II) surround the central dome (I). The different tools are color coded: microprofiler as blue circles, planar optode as black crosses, benthic chamber as white squares, push cores as green triangles (up) and gravity cores as yellow triangles (down) (map modified from Dupré et al., 2008).

used. On board, either $25 \mu \mathrm{L}{ }^{14} \mathrm{CH}_{4}$ (dissolved in water, $2.5 \mathrm{kBq}$ ) or $5-10 \mu \mathrm{L}$ carrier-free ${ }^{35} \mathrm{SO}_{4}^{2-}$ (dissolved in water, $50 \mathrm{kBq}$ ) were injected in $1 \mathrm{~cm}$ intervals through siliconsealed holes into the subcores (whole core injection method, Jørgensen, 1978). The sediments were incubated in the dark for $8-12 \mathrm{~h}$ at in situ temperature and afterwards sliced into $1 \mathrm{~cm}$ sections. Sediments incubated for methane oxidation were fixed in $25 \mathrm{~mL} \mathrm{NaOH}(2.5 \%$, w/v) in glass bottles that were immediately closed with rubber stoppers. Sediments for the sulfate reduction rate measurements were fixed in $20 \mathrm{~mL}$ zinc acetate solution $(20 \%$, w/v). The turnover rates of methane and sulfate were then determined in the home laboratory by scintillation counting and turnover rates calculated as previously described (Treude et al., 2003; Kallmeyer et al., 2004; Felden et al., 2010). The substrate concentrations were measured by gas chromatography (5890A, Hewlett Packard) and anion exchange chromatography (see pore water section) for methane and sulfate, respectively. Sulfate consumption was determined in 2006 and 2009, but AOM was only measured in 2006.

\subsubsection{Incubation experiment of center (I) and bacterial mat (II) sediments}

To test the effect of the Amon MV seep fluids on methaneand hydrocarbon-fueled SR, the upper $5 \mathrm{~cm}$ of sediments collected in 2009 from the bacterial mat area or the central area were gently mixed, divided into 9 replicates and diluted $(1: 3)$ with pore water originating either from their respective sampling site, or from the other area. As a third treatment, they were supplied with anaerobic growth medium for sulfate-reducing bacteria (Widdel and Bak, 1992). Each treatment had three replicates. Subsequently, sediments were incubated at in situ temperature with $10 \mu \mathrm{L}$ carrier-free ${ }^{35} \mathrm{SO}_{4}^{2-}$ in headspace-free glass vials for $10.5 \mathrm{~h}$. The reaction 
was terminated with $\mathrm{ZnAc}$ and samples were processed as described in the Sect. 2.2.1.

\subsection{Geochemistry}

\subsubsection{Methane concentration}

Sediment methane concentrations were determined from subsamples obtained by slicing sediment cores in $2-3 \mathrm{~cm}$ intervals. Of each sediment horizon $3 \mathrm{~mL}$ were quickly transferred with a cut-off syringe into a $25 \mathrm{~mL}$ glass bottle containing $5 \mathrm{~mL} \mathrm{NaOH}(2.5 \%$, w/v). The glasses were immediately closed with butyl rubber stoppers and were shaken in order to release the dissolved pore water methane into the headspace. The methane concentrations were measured by injecting $100 \mu \mathrm{L}$ of the glass bottle headspace into a gas chromatograph (5890A, Hewlett Packard).

\subsubsection{Pore water extraction}

Pore water from two replicate PCs per habitat in 2006 and one PC in 2009 was extracted with Rhizons (Rhizon CSS: length $5 \mathrm{~cm}$, pore diameter $0.15 \mu \mathrm{m}$; Rhizosphere Research Products, Wageningen, Netherlands) in $1 \mathrm{~cm}$ resolution and immediately fixed in $5 \% \mathrm{ZnAc}$ for sulfate, chloride, and sulfide analyses. Furthermore, samples for dissolved inorganic carbon (DIC) were preserved by adding $\mathrm{HgCl}_{2}$ and stored headspace free in gas tide glass vials. The extraction of pore water from GC sediments was either performed by centrifugation according to de Lange (1992) in 2006 or with Rhizons in 2009. All samples were stored at $4{ }^{\circ} \mathrm{C}$ until analyses in the home laboratory.

\subsubsection{Pore water analyses}

Sulfate and chloride concentrations in the PC pore waters were measured by non-suppressed anion exchange chromatography (Waters IC-Pak anion exchange column, waters 430 conductivity detector) after filtration and dilution. The total sulfide concentrations $\left(\mathrm{H}_{2} \mathrm{~S}+\mathrm{HS}^{-}+\mathrm{S}^{2-}\right)$ were determined with the diamine complexation method (Cline, 1969). DIC concentrations were measured with the flow injection method (conductivity detector: VWR scientific model 1054) according to Hall and Aller (1992). Interfering dissolved sulfide in the samples was eliminated before the DIC measurement by adding $0.5 \mathrm{M}$ molybdate solution as described by Lustwerk and Burdiger (1995). In 2006 the reported sulfate and chloride data from GCs were analysed using inductively coupled plasma optical emission spectrometry (ICP-OES); these results were verified using on-board-acidified and $\mathrm{N}_{2}$ bubbled subsamples. The pore water salinity was determined with a conventional refractometer on board. In 2009, sulfate and chloride concentrations in GC pore waters were determined by non-suppressed anion exchange chromatography as described above.

\subsubsection{Porosity of sediments}

The porosity of sediments was calculated from water content, after measuring wet and dry weight of a defined sediment volume. It was $0.7 \pm 0.1$ for all sediments averaged over the top $3 \mathrm{~m}$.

\subsection{Acridine orange direct counts (AODC)}

To determine the total number of single cells with acridine orange direct counts, sediment sections were preserved in artificial seawater with $2 \%$ formalin. The Acridine Orange staining was performed in the home laboratory based on previously described methods (Meyer-Reil, 1983; Boetius and Lochte, 1996). For each sample, two replicate filters and at least 30 grids per filter were randomly counted and only single cells were considered.

\subsection{In situ measurements}

\subsubsection{Benthic chamber}

Total benthic oxygen uptake (TOU) and total methane efflux (only measured in 2009) were determined with a benthic chamber module equipped with two Clark-type oxygen mini-electrodes or oxygen optodes (AADI, Norway) by the ROV QUEST 4000 to ensure targeted measurements at selected spots. The method was carried out according to Felden et al. (2010) and details are provided in the supplements.

\subsubsection{Microprofiler}

To measure high-resolution gradients at visually targeted sites, a deep-sea microprofiler module was operated by the ROV. During the autonomous measurements, the microsensors mounted to the microprofiler module were vertically driven in $250 \mu \mathrm{m}$ steps from the water column to a sediment depth of up to $10 \mathrm{~cm}$ (de Beer et al., 2006). At each deployment, two $\mathrm{pH}$, two sulfide, and two oxygen microelectrodes (Revsbech et al., 1983; Revsbech and Ward, 1983; Jeroschewski et al., 1996) were used. Temperature gradients in the top few $\mathrm{cm}$ ( $T$ gradient surface) were recorded with a temperature sensor (Pt100, UST Umweltsensortechnik $\mathrm{GmbH}$ ). All sensors were calibrated on board according to previously described methods (Wenzhöfer et al., 2000; de Beer et al., 2006). Total sulfide $\left(\mathrm{H}_{2} \mathrm{~S}+\mathrm{HS}^{-}+\mathrm{S}^{2-}\right)$ profiles were calculated from the $\mathrm{H}_{2} \mathrm{~S}$ and the $\mathrm{pH}$ profiles. All calculations were carried out according to Lichtschlag et al. (2010a) and details are provided in the supplements. In 2009, the microsensor sulfide measurements at the Amon MV failed due to problems with the profiler module for sulfide microelectrodes. 


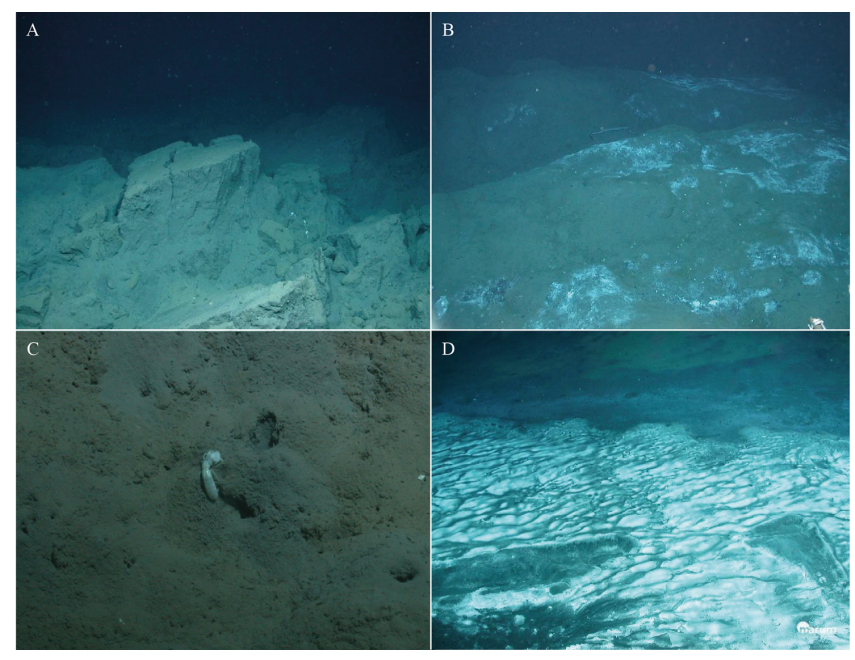

Fig. 2. Different cold-seep habitats of the Amon MV. At the central dome (I), degassing of the seafloor created bathymetric anomalies of several meters in height in 2006 (A). Around the central dome, the seafloor becomes smoother and bacterial mats (II) are found covering the hummocks (B). Biogenic mounds of up to half a meter in height (III) comprise the largest habitat of the Amon MV and are formed by mud shrimps (C). A unique feature at the outer rim of the Amon MV is the lateral outflow of sulfidic muds ("sulfur band") (D). All pictures are copyright of MARUM, Bremen.

\subsubsection{In situ subsurface sediment temperature measurements}

In situ sediment temperature measurements were carried out with gravity corers equipped with MICREL THP temperature loggers during both expeditions in 2006 and 2009 (for detail see Feseker et al., 2008). The loggers were mounted on outriggers welded on the corer barrel. The sensors were calibrated to a precision of $0.002^{\circ} \mathrm{C}$. The temperature loggers remained in the sediment for a period of 7-10 min, during which each logger recorded the sediment temperature at a time interval of $5 \mathrm{~s}$. The equilibrium temperatures were calculated through extrapolation of the recorded equilibration curves (Villinger and Davis, 1987).

\section{Results}

We distinguished four different habitats of the Amon MV (Fig. 2): (I) the central dome area is ca. $250 \mathrm{~m}$ in diameter and characterized by gas expulsions and mud breccia extrusions. Besides the detection of gas flares by the ship's acoustic sonar, we observed release of gas bubbles upon ROV touchdown and sampling, indicating gas overpressure at $1250 \mathrm{~m}$ water depth. In 2006 we observed blocks of greyish mud with sharp edges separated by cracks and troughs of several meters in width and height, indicating processes of seafloor displacement. In 2009 these blocks were partially eroded and their edges considerably smoothened, as indicated by visual observation with the ROV. At the northern boundary of the central dome, we could not observe any indications of recent gas ebullition or bacterial mats at the seafloor ("transition zone" Ia). (II) Surrounding the central dome structure was an area of about $50 \mathrm{~m}$ width characterized by smooth ripples, marked by more stabilized sediments. The seafloor was covered by $10-20 \%$ with patches of bacterial mats and black sediment spots with a diameter of a few decimetres to meters. No signs of recent eruptions were found in this area, neither in 2006 nor 2009. The variable distribution and size of the mat patches in the central area suggest a spatially heterogeneous, but temporally persistent outflow of seep fluids in this habitat, as indicated by constant surficial temperature gradients in 2006 and 2009 (Fig. 5b, e). (III) The largest part of the Amon MV was covered by biogenic mounds of $20-50 \mathrm{~cm}$ in height and width, formed by thalassinid mud shrimps. Fresh burrows of the shrimps were characterized by lumps of greyish reduced subsurface sediments deposited on the beige surface muds (Fig. 2c). (IV) A lateral outflow of briny mud, called "sulfur band", was detected at the foot of the MV (southwestern area) (Girnth et al., 2011).

\subsection{Methane efflux and temperature gradients}

High methane effluxes, defined as the amount of dissolved methane being emitted from the seafloor to the water column, were measured at the central dome (I) and associated with bacterial mats (II) (Table 1). No methane efflux was detected at the biogenic mounds, the bacterial mat of the lateral mud flow "sulfur band (IV)" or the reference area. Hence, methane efflux was restricted to areas of high temperature gradients (Table 1). Surface and subsurface T gradient measurements showed similar trends of rapid cooling from the inner center of the Amon MV towards its outer zone, as well as a decrease in temperature between 2006 and 2009. The highest sediment temperature was observed in 2006 with $70^{\circ} \mathrm{C}$ at several meters depth below surface. In 2009 the highest overall temperature was $50^{\circ} \mathrm{C}$.

\subsection{Methane and other pore water constituents}

The sediments from the central dome (I) were gas saturated at a water depth of $1120 \mathrm{~m}$ and an in situ temperature of $14^{\circ} \mathrm{C}$, which indicates an equilibrium methane concentration of at least $140 \mathrm{mM}$ at the seafloor (Yamamoto et al., 1976). However, due to depressurization and degassing during core retrieval, ex situ measured methane concentrations were only about $2 \mathrm{mM}$ throughout the entire cores (data not shown). Degassing of samples from the central dome may have affected also ex situ sulfide and DIC concentrations, which are shown in Figs. 3 and 4. The sulfide concentration profiles (Fig. 3) indicated substantial sulfide and DIC production in the top $15 \mathrm{~cm}$ of the bacterial mat (II) habitat, together with sulfate depletion below $15 \mathrm{~cm}$ sediment depth. In contrast, sulfide production was low at the central dome, despite the 
Table 1. Overview of data from the four main Amon MV habitats. Surface and subsurface T gradients were measured in situ with microsensor and T-lance measurements, respectively. Methane efflux and total oxygen uptake (TOU) was measured with the benthic chamber. The dissolved oxygen uptake (DOU), and upward diffusive sulfide flux were calculated based on in situ microsensor measurements. The averaged sulfate reduction (SR) and methane oxidation rates (AOM) were integrated over the first $15 \mathrm{~cm}$. Single cells determined by AODC were depth integrated over the first $2 \mathrm{~cm}$ of the sediment. (n.d. = not determined; $n=$ numbers of replicates if available).

\begin{tabular}{|c|c|c|c|c|c|c|}
\hline & & central dome (I) & bacterial mat zone (II) & biogenic mounds (III) & sulfur band (IV) & reference \\
\hline \multirow[t]{2}{*}{ Position } & & $32^{\circ} 22.16^{\prime} \mathrm{N}$ & $32^{\circ} 22.13^{\prime} \mathrm{N}$ & $32^{\circ} 22.12^{\prime} \mathrm{N}$ & $32^{\circ} 22.05^{\prime} \mathrm{N}$ & \\
\hline & & $31^{\circ} 42.64^{\prime} \mathrm{E}$ & $31^{\circ} 42.66^{\prime} \mathrm{E}$ & $31^{\circ} 42.35^{\prime} \mathrm{E}$ & $31^{\circ} 42.27^{\prime} \mathrm{E}$ & \\
\hline Area $\left(m^{2}\right)$ & & $8000^{1}$ & $10000^{2}$ & $1900000^{1}$ & $200^{2}$ & n.d \\
\hline$T$ gradients & 2006 & $17.2(n=1)$ & $2.7(n=1)$ & n.d. & $0(n=2)$ & n.d \\
\hline surface $\left({ }^{\circ} \mathrm{C} \mathrm{m}^{-1}\right)$ : & 2009 & $2.3(n=1)$ & $2.7(n=1)$ & n.d. & $0(n=3)$ & n.d \\
\hline$T$ gradients & 2006 & \multicolumn{2}{|c|}{$7.39(n=6 ; \min .5 .65 ; \max .9 .09)$} & \multicolumn{2}{|c|}{$0.62(n=7 ; \min .0 .04 ; \max .2 .37)$} & $0.02^{4}$ \\
\hline subsurface $\left({ }^{\circ} \mathrm{C} \mathrm{m}^{-1}\right)$ : & 2009 & \multicolumn{2}{|c|}{$5.58(n=13 ; \min .0 .57 ; \max .5 .65)$} & \multicolumn{2}{|c|}{$0.34(n=33 ; \min .0 .04 ; \max .2 .13)$} & \\
\hline $\mathrm{CH}_{4}$-efflux & 2006 & n.d. & n.d. & $0(n=3)^{5}$ & n.d. & $0(n=3)^{5}$ \\
\hline$\left(\mathrm{mmol} \mathrm{m}^{-2} \mathrm{~d}^{-1}\right)$ : & 2009 & $1 ; 24 ; 70(n=3)$ & $49 ; 83 ; 85(n=3)$ & n.d. & $0(n=1)$ & n.d \\
\hline TOU & 2006 & n.d. & $50(n=1)$ & $5(n=1)$ & $35 ; 71(n=2)$ & n.d \\
\hline$\left(\mathrm{mmol} \mathrm{m}^{-2} \mathrm{~d}^{-1}\right)$ : & 2009 & $19 ; 102(n=2)$ & $69(n=1)$ & n.d. & $119(n=1)$ & n.d \\
\hline DOU & 2006 & $10(n=1)$ & $40 ; 44(n=2)$ & n.d. & $11 ; 12 ; 26 ; 46(n=4)$ & $1.3^{3}(n=1)$ \\
\hline$\left(\mathrm{mmol} \mathrm{m}^{-2} \mathrm{~d}^{-1}\right)$ & 2009 & $11(n=1)$ & $47(n=1)$ & n.d. & $3 ; 6(n=2)$ & n.d \\
\hline$J_{\text {(upward diffusive sulfide-flux) }}$ & 2006 & $0(n=1)$ & $40(n=1)$ & n.d. & $0 ; 1 ; 1 ; 20(n=4)$ & $0^{3}(n=1)$ \\
\hline$\left(\mathrm{mmol} \mathrm{m}^{-2} \mathrm{~d}^{-1}\right)$ & 2009 & n.d. & n.d. & n.d. & n.d. & n.d. \\
\hline SR & 2006 & $3.1-6.8(n=4)$ & $18.5-55.4(n=4)^{*}$ & $0-0.5(n=4)$ & $0.3-0.7(n=3)$ & $0-0.1(n=3)$ \\
\hline$\left(\mathrm{mmol} \mathrm{m}^{-2} \mathrm{~d}^{-1}\right)$ : & 2009 & $0.8-2.0(n=3)$ & $4.6-26.4(n=3)$ & n.d. & $0.6-89.2(n=9)$ & n.d. \\
\hline AOM & 2006 & $0-1.5(n=4)$ & $6.5-44.7(n=6)$ & $0-0.1(n=4)$ & $0.1(n=3)$ & $0(n=3)$ \\
\hline$\left(\mathrm{mmol} \mathrm{m}^{-2} \mathrm{~d}^{-1}\right)$ : & 2009 & n.d. & n.d. & n.d. & n.d. & n.d \\
\hline Single cells & 2006 & $0.46 \pm 0.08(n=4)$ & $4.14 \pm 1.96(n=10)$ & $0.60 \pm 0.30(n=4)$ & $5.62 \pm 1.36(n=8)$ & $1.74 \pm 0.60(n=4)$ \\
\hline$\left(\times 10^{13}\right.$ cells per $\left.\mathrm{m}^{2}\right)$ & 2009 & $1.24 \pm 0.60(n=4)$ & $3.7 \pm 0.76(n=4)$ & n.d. & $6.60 \pm 1.60(n=16)$ & n.d. \\
\hline
\end{tabular}

${ }^{1}$ Dupré et al. (2007); ${ }^{2}$ Grünke et al. (2011); ${ }^{3}$ ex situ data by Ritt et al. (2011); ${ }^{4}$ Feseker et al. (2008); ${ }^{5}$ according to sediment methane concentration profiles. * One outlier with extraordinarily high sulfate consumption rates $\left(138 \mathrm{mmol} \mathrm{m}^{-2} \mathrm{~d}^{-1}\right)$ was not further considered as there was no replicate measurement available for confirmation.

high methane and sulfate concentrations (I). Sulfate concentrations increased from $30 \mathrm{mM}$ to up to $40 \mathrm{mM}$ in the top $14 \mathrm{~cm}$ (Fig. 3), indicating an upflow of sulfate- and DIC-rich subsurface fluids at the central dome (Figs. 3 and 4, I). Upflow of sulfate-rich subsurface fluids was confirmed by additional pore water profiles obtained from gravity cores, which showed sulfate concentration of up to $100 \mathrm{mM}$ (3-times seawater concentration) at about $350 \mathrm{~cm}$ bsf (Fig. 4). In contrast, chloride concentrations decreased from close to seawater values at the sediment surface to less than $130 \mathrm{mM}$ at $250 \mathrm{~cm}$ bsf at the central dome (Fig. 4). Differences between 2006 and 2009 were difficult to quantify because of the high heterogeneity of sediments and subsurface fluid flow in the inner dome and the surrounding bacterial mat zone (Table 1).

Only low (maximum $0.007 \mathrm{mM}$ ) ex situ methane concentrations were found at the northern transition (Ia), indicating the absence of seepage. Here, sulfate (average $34 \mathrm{mM}$ ), chloride (average $547 \mathrm{mM}$ ) and DIC (average $2.8 \mathrm{mM}$ ) were constant with depth, confirming the absence of upward advecting fluids. In the surface sediment $(0-15 \mathrm{~cm})$ from the biogenic mounds (III) no methane or sulfide were detected. All analysed pore water constituents had values close to seawater concentrations (Fig. 3).

In sediments of the "sulfur band" mud flow (IV) at the base of the Amon MV in 2006, methane concentration was slightly elevated in the topmost surface sediments
$(0.01 \mathrm{mM})$, but was not detected deeper than $3 \mathrm{~cm}$ bsf. Sulfide concentrations were also low and restricted to the top few $\mathrm{cm}$, indicating lateral surface transport in accordance with visual observations of brine flow (in detail described in Girnth et al., 2011). Furthermore, no decrease in sulfate or increase in DIC (Fig. 3) was observed in the mud underlying the microbial mat. However, in 2009 a substantial increase in methane was recorded $(0.3 \mathrm{mM})$, which co-occurred with a depletion of sulfate and an increase of sulfide. Also, the chloride concentration in the sediment was elevated up to $990 \mathrm{mM}$ (nearly 2-times seawater concentration) at $9 \mathrm{~cm}$ bsf, indicating the influence of temporally variable brine flow in this habitat of the Amon MV. This is in contrast to the chloride depletion of vertically rising subsurface fluids reaching the top of the central dome, indicating different processes of fluid formation, alteration, and transport below the MV.

\subsection{In situ oxygen and sulfide fluxes}

Oxygen and sulfide fluxes measured in situ serve as indicators of microbial activity. The difference between oxygen and sulfide fluxes at background sites to those associated with hydrocarbon seepage can be related to aerobic and anaerobic hydrocarbon oxidation. At the bacterial mat (II) site characterized by high methane fluxes, the sulfide profiles indicated a substantial production of sulfide directly below the bacterial mat. The sulfide was entirely consumed with 

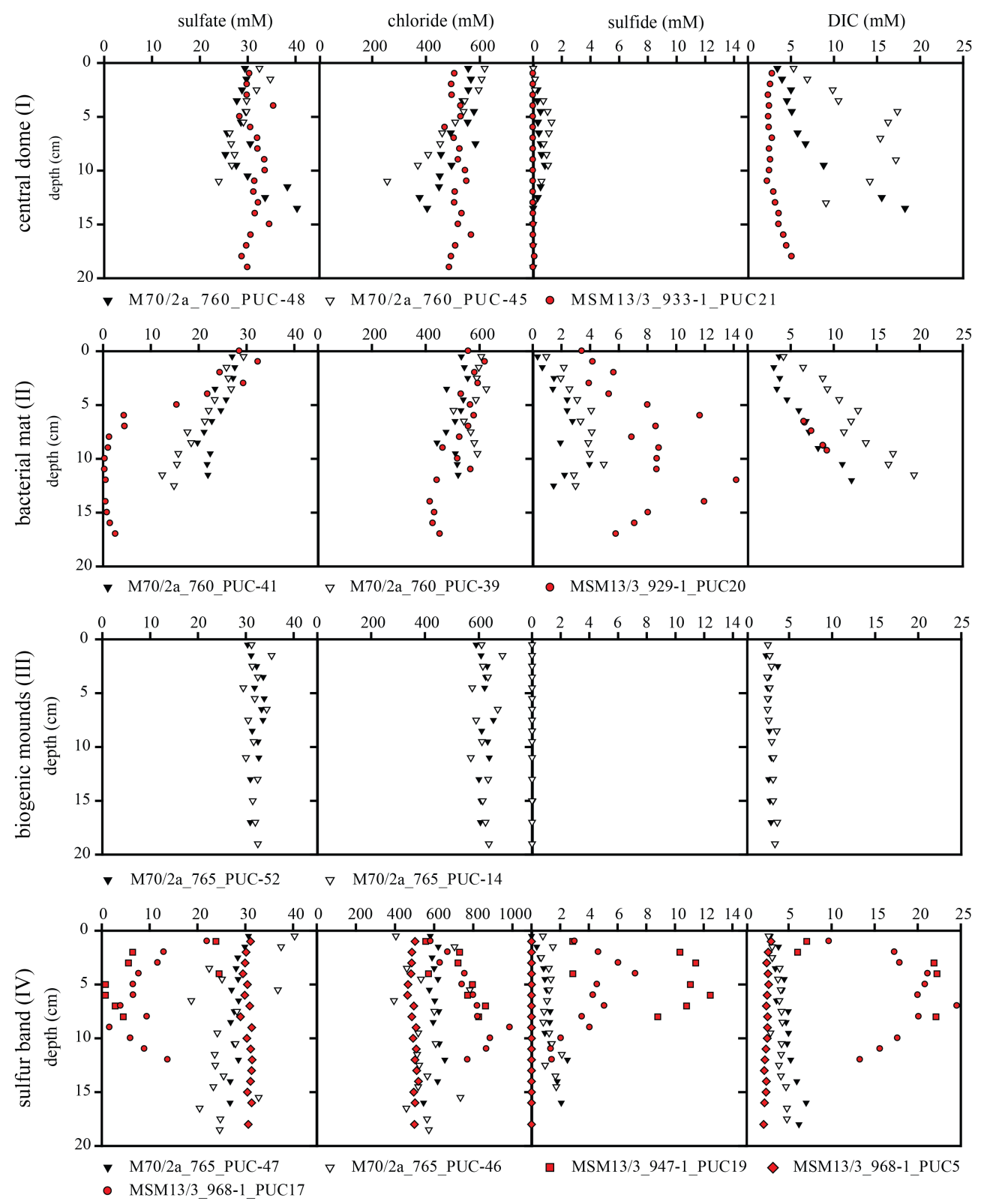

Fig. 3. Pore water data of sulfate, chloride, sulfide, and DIC (columns) from the four Amon MV habitats (rows): central dome (I), bacterial mat (II), biogenic mounds (III), and sulfur band (IV). The black and white symbols indicate replicate cores of the same station in 2006. Red symbols indicate pore water samples collected in 2009. Please note the different x scale of chloride in the lowest panel.

oxygen within the sediment before it reached the water column. This site showed a limited penetration of oxygen of $<1 \mathrm{~mm}$ (Fig. 5) following the sediment topography (Supplement Fig. 1). In contrast, at the highly methane vented and disturbed central dome (I), oxygen penetrated 3-4 mm into the sediment (Table 1). No sulfide production was detected in the upper $2 \mathrm{~cm}$, matching the pore water data and microbial rate measurements, and $\mathrm{pH}$ showed a continuous decrease with depth. At the biogenic mounds (III) characterized by an absence of methane transport, oxygen penetration reached several $\mathrm{cm}$ into the seafloor due to bioturbation by mud shrimps, excluding AOM.

Total oxygen flux measured with the benthic chambers comprises the total benthic respiration rates including microorganisms and animals. The TOU was 1-2 orders of magnitude higher at the central dome (I) and bacterial mat (II) sites than at the biogenic mounds (III) (Table 1), hence correlated with methane transport. Furthermore, in 2009 total oxygen uptake (TOU) was slightly higher than in 2006 (Table 1). 


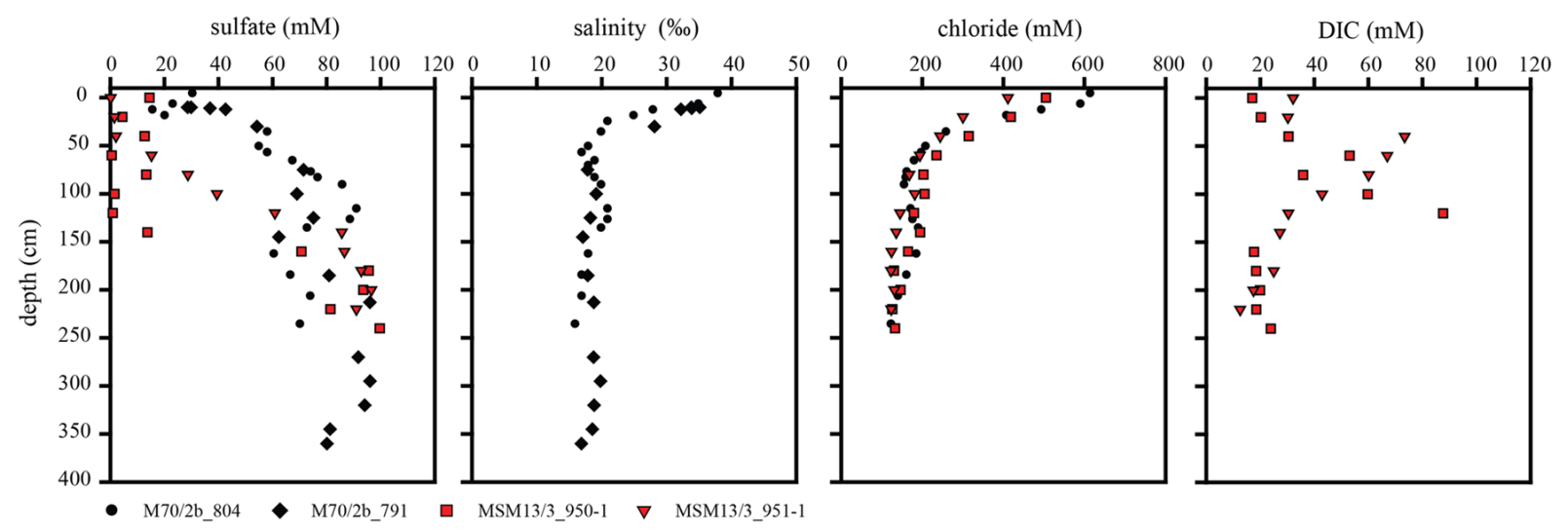

Fig. 4. Sulfate, chloride concentrations, and salinity from deeper coring of the central dome of the Amon MV. Years 2006 and 2009 are indicated by black and red symbols, respectively.

\subsection{Methane and sulfate consumption}

Substantial differences in AOM and SR depth integrated rates $(0-15 \mathrm{~cm})$ were detected between the different habitats of Amon MV (Fig. 6; Table 1). The highest hydrocarbon turnover was detected in the upper $5 \mathrm{~cm}$ of sediment and associated with the patchy bacterial mats surrounding the central dome (II) (Fig. 6d). In the gas-oversaturated sediments of the central dome of Amon MV (I), SR values were considerably lower (Fig. 6a), despite the co-occurrence of methane and sulfate throughout the core. AOM was up to 5 times lower than SR (Fig. 6b), indicating that a substantial fraction of sulfate reduction was based on the anaerobic oxidation of higher hydrocarbons (see Mastalerz et al., 2009 for gas composition). At the biogenic mounds (III), SR and AOM rates (Fig. 6g, h) were mostly at the detection limit in the top $15 \mathrm{~cm}$ due to the very low methane content of these sediments. At the sulfur band (IV), where the briny mud was covered by a whitish microbial mat (Fig. 6j, k), sulfate and methane turnover was restricted to the upper $3 \mathrm{~cm}$ of the blackish sediment (SR maximum $26 \mathrm{nmol} \mathrm{mL}^{-1} \mathrm{~d}^{-1}$ ) in 2006. In this region in 2009, much higher sulfate consumption rates of $>1000 \mathrm{nmol} \mathrm{mL}^{-1} \mathrm{~d}^{-1}$ were found over the entire investigated depth range.

To investigate the potential repression of hydrocarbonfueled sulfate reduction by pore water fluids from the main gas conduit, we carried out a pore water transplantation experiment with sediments from the central dome and the surrounding active bacterial mat-covered sediments (Fig. 7). The sediments containing the natural microbial communities were mixed with pore waters of either site, or were replaced with sulfate reducer medium amended with methane, and the resulting sulfate reduction rates was measured in replicate slurries. The experiment showed that SR rates remained unaffected by the pore water composition. They were low in center sediments and high in sediments from a bacterial mat, even when pore waters of the central dome area were added.

\subsection{Cell counts}

In sediments of the Amon MV central dome (I), total cell numbers in the top $15 \mathrm{~cm}$ were surprisingly low, decreasing with increasing depth in 2006 (Fig. 6c). In 2009, cell abundances had substantially increased at the sediment surface. In the sediment below the bacterial mats (II, IV), the abundance of microbial cells (Fig. 6f, l) was much higher than in the inner dome sediments in 2006 and 2009. Both the Amon central dome and the biogenic mound sediments showed lower cell abundance than a reference core taken outside the Amon MV at a similar water depth.

\section{Discussion}

The aim of this study was to test several hypotheses related to the limitation of microbial activity in sediments of active MVs. Previous investigations as to the efficiency of the benthic microbial filter for hydrocarbons have shown that hydrocarbon-fueled sulfate reduction and methane consumption could be repressed by limitations in transport - e.g., low supply with electron acceptors (sulfate and oxygen, de Beer et al., 2006; Niemann et al., 2006), or by kinetic factors affecting microbial metabolism such as adverse chemical composition of subsurface fluids (Joye et al., 2009), by heat (Teske et al., 2002; Schouten et al., 2003; Brazelton et al., 2006, 2010), or by disturbances such as mud expulsion (Mastalerz et al., 2009). The Amon MV is an interesting natural laboratory to test these hypotheses as previous investigations have shown a wide range of geological and microbial activities associated with the different habitats of the Amon MV (Mastalerz et al., 2009; Omoregie et al., 2009; Dupré et al., 2010; Girnth et al., 2011; Grünke et al., 2011). We could confirm that despite the longevity of the Nile deep-sea fan gas seeps, the high supply of methane and sulfate, and the favorable bottom water temperatures of the deep Eastern Mediterranean of around $14^{\circ} \mathrm{C}$, the hydrocarbon-degrading 
A
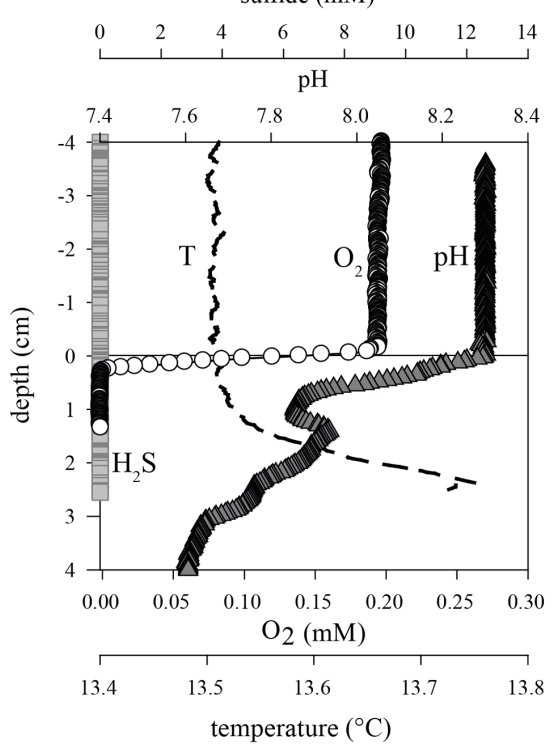

$\mathrm{D}$

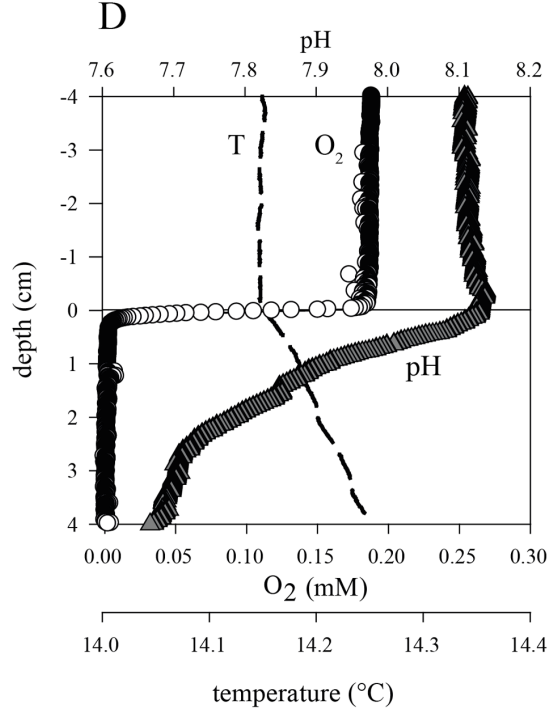

B
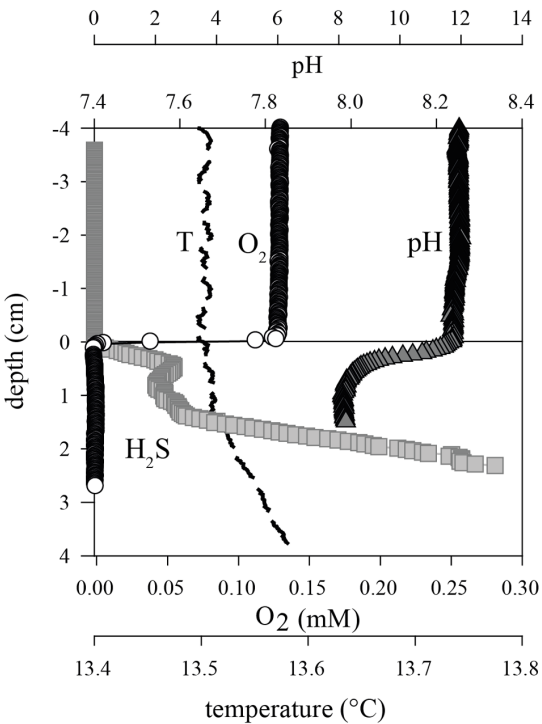

$\mathrm{E}$

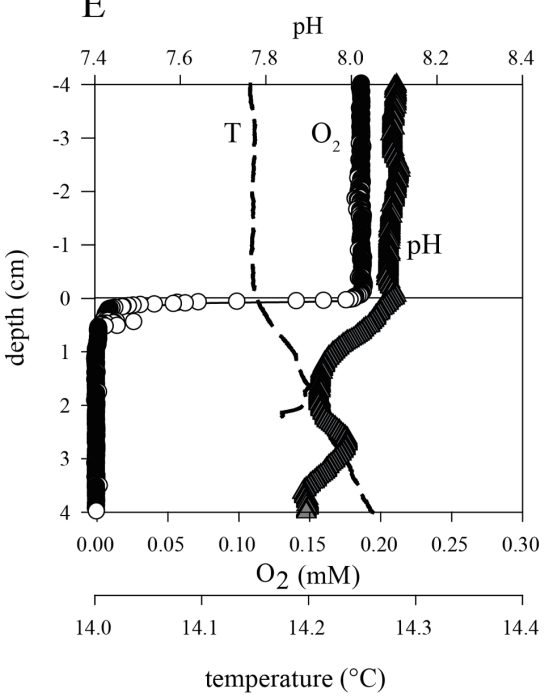

C
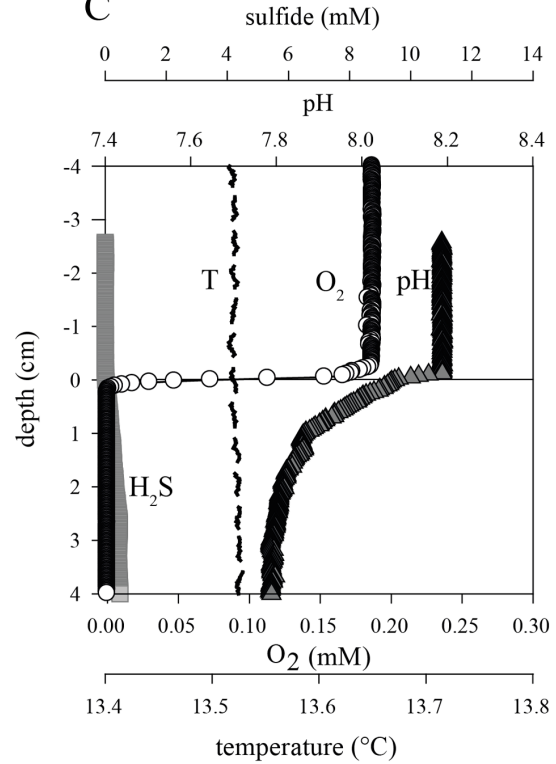

$\mathrm{F}$

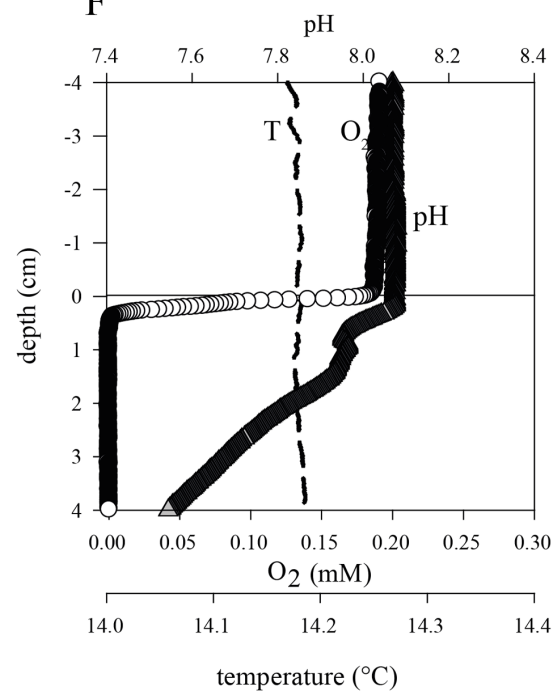

Fig. 5. Microsensor measurements from the (A), (D) central dome (I); (B), (E) the bacterial mat (II) site; (C), (F) the bacterial mats at the sulfur band (IV). The profiles show oxygen (O2) (white spheres), total sulfide (H2S) (grey line) concentrations, $\mathrm{pH}$ (grey triangles), and temperature (T, dashed line). (A-C) and (D-F) are profiles measured in 2006 and 2009, respectively. In 2009 no sulfide was measured due to failure of the respective microsensor units.

communities of Amon MV showed a low efficiency compared to other MVs. Only $2 \%$ of the total methane transported was consumed in the inner center, compared to $19 \%$ at the surrounding bacterial mats (Table 2). We investigated and compared limitations of the biogeochemical activities of all four major habitats of Amon MV (Fig. 2): (I) central dome, (II) bacterial mat zone, (III) biogenic mound zone, and (IV) a lateral mud flow at the flank of the MV named "sulfur band", considering both spatial and temporal variations.

\subsection{Transport limitation}

\subsubsection{Biogenic mound zone}

The largest area of the Amon MV comprised suboxic sediments covered by biogenic mounds (III). The mounds are built by thalassinid mud shrimps (Fig. 2f). Methane fluxes in the top $20 \mathrm{~cm}$ of seafloor were negligible, and concentrations too low to sustain active hydrocarbon-degrading microbial communities in the investigated surface sediments. However, as oxygen penetration was lower, and oxygen consumption $\left(5 \mathrm{mmol} \mathrm{m}^{-2} \mathrm{~d}^{-1}\right)$ higher than background values 


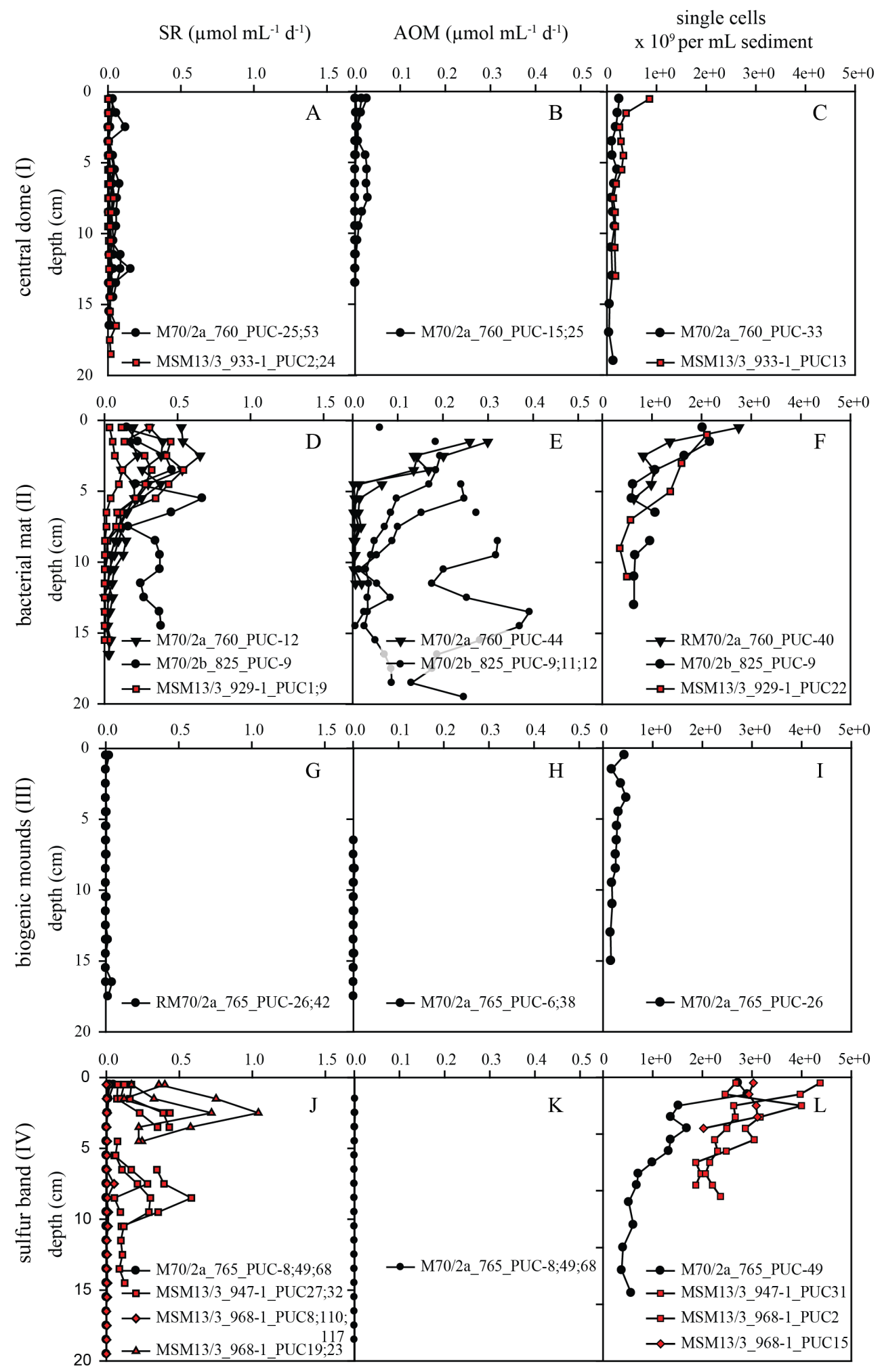

Fig. 6. Biogeochemistry of the different habitats at Amon MV. Sulfate reduction (left panel), anaerobic oxidation of methane (middle panel), and single cell counts (right panel) at (I) the central dome (A), (B), (C); (II) bacterial mats (D), (E), (F); (III) biogenic mounds (G), (H), (I); (IV) sulfur band (J), (K), (L). Replicates of one station are represented with the same symbol and the same year with the same color (black $=2006$, red $=2009$ ). Note: sulfate reduction and anaerobic oxidation of methane are on different scales. 
Table 2. Comparison of total oxygen uptakes (TOU), methane effluxes, SR rates, and temperature surface and subsurface gradients at the Amon MV, Håkon Mosby MV (HMMV), and Dvurechenskii (DMV). The efficiency of the anaerobic biological methane sink is calculated as the percentage of anaerobic oxidation of methane from the total methane flux (sum of $\mathrm{CH}_{4}$ efflux and methane oxidation).

\begin{tabular}{|c|c|c|c|c|c|c|}
\hline & $\begin{array}{l}T \text {-gradients*** } \\
\left({ }^{\circ} \mathrm{C} \mathrm{m}^{-1}\right)\end{array}$ & $\begin{array}{l}\text { TOU* }^{*} \\
\left(\mathrm{mmol} \mathrm{m}^{-2} \mathrm{~d}^{-1}\right)\end{array}$ & $\begin{array}{l}\text { Total } \mathrm{CH}_{4} \text { - efflux* } \\
\left(\mathrm{mmol} \mathrm{m}^{-2} \mathrm{~d}^{-1}\right)\end{array}$ & $\begin{array}{l}\mathrm{AOM}^{* *} \\
\left(\mathrm{mmol} \mathrm{m}^{-2} \mathrm{~d}^{-1}\right)\end{array}$ & $\begin{array}{l}\mathrm{SR}^{* *} \\
\left(\mathrm{mmol} \mathrm{m}^{-2} \mathrm{~d}^{-1}\right)\end{array}$ & $\begin{array}{l}\text { Biological } \\
\text { methane } \\
\text { sink }(\%)\end{array}$ \\
\hline \multicolumn{7}{|l|}{ Amon $\mathrm{MV}^{1}$ : } \\
\hline bacterial mat zone (II) & 3 & $50-69(n=2)$ & $71 \pm 20(n=3)$ & $17.2 \pm 14.1(n=6)$ & $54.1 \pm 49(n=5)$ & 19 \\
\hline biogenic mounds (III) & n.d. & $5(n=1)$ & n.d. & $0.1 \pm 0.1(n=4)$ & $0.2 \pm 0.2(n=4)$ & n.d. \\
\hline \multicolumn{7}{|l|}{$\mathrm{HMMV}^{2}$ : } \\
\hline center & $7-27$ & $15-72(n=4)$ & $58-777(n=4)$ & $4.1 \pm 3.7(n=18)$ & $0.4 \pm 0.3(n=15)$ & 4 \\
\hline bacterial mat zone & $4-5$ & $60-114(n=3)$ & $25-78(n=2)$ & $9.4 \pm 5.6(n=18)$ & $24.2 \pm 23.8(n=46)$ & 21 \\
\hline Siboglinid tubeworms & 2 & $161(n=1)$ & $2(n=1)$ & $2.3 \pm 3.0(n=6)$ & $6.5 \pm 7.0(n=6)$ & 90 \\
\hline \multicolumn{7}{|l|}{$\mathrm{DMV}^{3}$ (anoxic system): } \\
\hline center & 10 & - & $458(n=1)$ & $0.1 \pm 0.1(n=3)$ & $0.1 \pm 0(n=3)$ & $<1$ \\
\hline western rim & 0.2 & - & n.d. & $11.2 \pm 9.6(n=3)$ & $108 \pm 38(n=3)$ & n.d. \\
\hline
\end{tabular}

* measured by in situ benthic chamber incubations,

** depth integrated rates (Amon MV, HMMV $=0-15 \mathrm{~cm} ; \mathrm{DMV}=0-10 \mathrm{~cm}$ ),

$* * *$ calculated based on in situ microsensor (Amon MV, DMV) or $T$-probe measurements (HMMV),

1 this study,

2 from Felden et al. (2010),

3 from Lichtschlag et al. (2010b). Note that the DMV lies in anoxic waters.

of non-seep-influenced seafloor at similar water depths outside of the Amon MV $\left(1.3 \mathrm{mmol} \mathrm{m}^{-2} \mathrm{~d}^{-1}\right)$, we assume that this zone is still influenced by low rates of subsurface hydrocarbon transport, which may be efficiently utilized by subsurface microbial communities for which the mud shrimps may dwell.

A specific association of mound-forming mud shrimps with mud volcanism has been previously observed in the Eastern Mediterranean deep sea (Dupré et al., 2008), and is also known from the fossil record (Amano and Kiel, 2007). The cause of their association with cold-seep ecosystems remains unknown, but may be due to the effects of mud volcanism on the seafloor substrate (less consolidated muds), and probably also due to the grazing of bacterial communities becoming enriched at the redox boundaries. A similar type of ecosystem engineering is known from the coastal mud shrimp Callianassa. These live on organic material, mainly sea-grass debris, and its associated microorganism (Ziebis et al., 1996; Dworschak, 2001; Abed-Navandi and Dworschak, 2005).

\subsubsection{Sulfuric mud flow "sulfur band" at the base of Amon}

The source area of the mud flow was littered with shells of thyasirid bivalves, indicating that the foot of the Amon MV is a highly dynamic environment (Ritt et al., 2011). In 2006 the mud flow appeared fresh, as the blackish reduced muds were exposed at the source of the flow, and partially covered by brine. With increasing distance from the source, they were densely covered by a whitish mat of Thiomargarita namibiensis (Fig. 2d) (Girnth et al., 2011). Benthic chamber measurements indicated a substantial efflux of sulfide, with high- est values at the source of the mud flow, decreasing with increasing distance along the sulfur band (Girnth et al., 2011). However, in 2006 methane concentrations were very low, rates of microbial sulfate reduction and AOM were close to detection limit, and no in situ sulfide production was detected in the sediments (Figs. 3, 5). Accordingly, we found rather low cell numbers below the bacterial mat and concluded that most of this sulfide was transported laterally along with the briny outflow and not produced in the sediments. In 2009 the situation had changed considerably, and methane transport, microbial sulfate reduction as well as total oxygen consumption and cell numbers had increased substantially (Table 1), indicating the development of active hydrocarbon degrading anaerobic communities. Surrounding the mud flow, active chemosynthetic communities were observed in 2006 and 2009, consisting mainly of Lamellibrachia tubeworms (Duperron et al., 2009) and bivalves associated with carbonate crusts (Ritt et al., 2011). The finding of such lateral mud flows supporting chemosynthetic communities indicates that methane transport may not be restricted to the central areas of MV and illustrates the need for systematic surveys of seafloor structures like MVs (Omoregie et al., 2008).

\subsection{Kinetic limitation by disturbance and heat in the central area}

It has previously been shown that in MV centers with high seepage rates of $>1 \mathrm{~m} \mathrm{yr}^{-1}$, the upward flow of sulfatedepleted fluids can restrict the downward diffusion of sulfate from the water column into deeper sediment strata, thus limiting SR and AOM to the topmost sulfate-penetrated horizons (de Beer et al., 2006; Lichtschlag et al., 2010a). However, at Amon MV, subsurface fluids are enriched in 

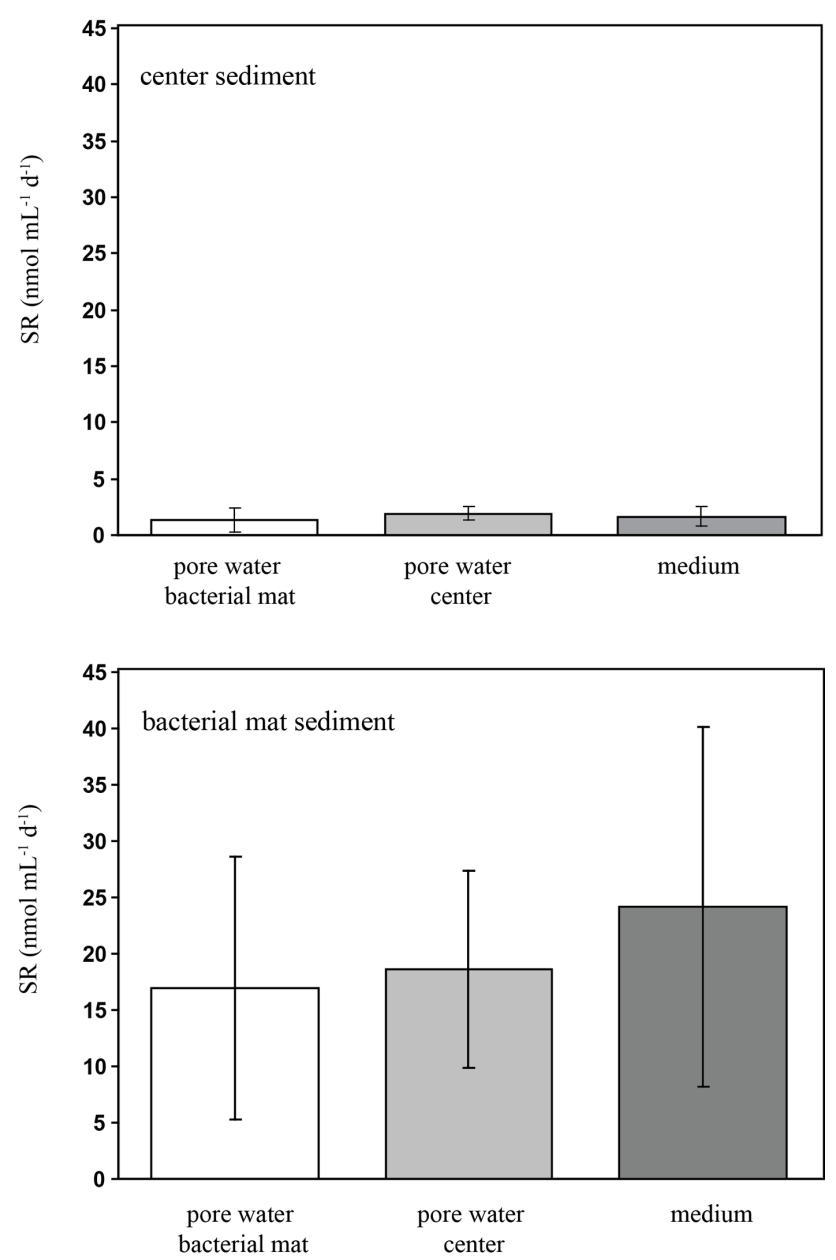

Fig. 7. SR inhibition experiment. Error bars indicate standard deviation $(N=6)$.

sulfate, and hence electron acceptor limitation cannot explain the low AOM and SR rates. Therefore, we searched for kinetic explanations.

To further test whether the uprising Amon MV fluids could contain substances repressing sulfate reduction, sediments from the center (I) and bacterial mat (II) sites were incubated on board with gas-enriched pore water extracted from the central dome, the bacterial mat zone or with sulfate reducer medium amended with methane. Results showed that methane-fueled SR activity in samples containing the microbial communities from either habitat remained the same, independent of the origin of the pore water amended (Fig. 7). Hence, we can exclude that anaerobic hydrocarbon degradation in the central dome zone is inhibited by potentially toxic compounds co-migrating with the fluids and gases.

The central dome area of Amon MV showed the steepest temperature gradient and was characterized by elevated mud breccia blocks. These observations indicate recent gas outbursts and disturbances of the seafloor. Subsurface seafloor temperatures in the central gas conduit reach up to at least $70^{\circ} \mathrm{C}$, as recorded in 2006 . The currently known upper temperature limit for AOM and growth of anaerobic methanotrophic communities is around $65^{\circ} \mathrm{C}$ (Kallmeyer and Boetius, 2004; Holler et al., 2011). Hence, it may be that anaerobic methanotrophs cannot populate subsurface muds and fluids at Amon MV, despite the high availability of methane and sulfate. Expulsions of hot fluids and subsurface muds to the seafloor of the central area are likely to repress microbial communities able to oxidize methane anaerobically. Only after cooling, could these gas- and sulfateladen sediments be repopulated by microbial communities. But given the very slow growth of anaerobic hydrocarbon degraders with generation times of 6-12 months (Nauhaus et al., 2007; Knittel and Boetius, 2009), it may take years before active microbial communities develop in such freshly exposed subsurface muds to control hydrocarbon emissions. Accordingly, the relatively high total oxygen consumption rates detected suggest a dominance of more rapidly growing aerobic hydrocarbon degraders in this area.

In contrast, at the boundary of the central dome, the surface of the seafloor changed from a highly disturbed landscape (Fig. 2a) to smoother eroded mud breccia covered by bacterial mats (Dupré et al., 2007). These sediments were cooled sufficiently long to allow colonization of AOM. This explains best why - despite the high availability of methane and sulfate in both habitats - anaerobic microbial activity (sulfide production, SR and AOM) was much lower in the center than in the bacterial-mat-covered areas (Fig. 6a; Table 1). Supporting this hypothesis, we found rather low cell abundances in sediments of the inner Amon MV center (Fig. 6c), which were 1-2 orders of magnitude lower than cell numbers usually found in similar sediment horizons at active cold seeps (Knittel and Boetius, 2009). They were also an order of magnitude lower than cell numbers of surface sediments in the bacterial mat zone.

Also, the temporal change observed in the bacterial mat zone indicates a further development of the hydrocarbon degrading community. Between 2006 and 2009 (Fig. 3), sulfate became depleted in the sediment below $10 \mathrm{~cm}$, causing lower integrated sulfate reduction rates, and indicating the onset of transport limitation. Accordingly, the DIC concentration profile had increased substantially between 2006 and 2009, indicating an overall increase in hydrocarbon conversion. This further supports the above hypothesis that the development of an active anaerobic hydrocarbon-degrading community may take years before controlling efficiently hydrocarbon emission and developing a strong signal in the pore water gradients.

\section{Conclusions on limitations of microbial activity at cold-seep ecosystems}

The microbial and faunal activity at cold seeps is primarily linked to hydrocarbon transport and fluid flow (e.g., Dubilier 
et al., 2008; Felden et al., 2010; Lichtschlag et al., 2010a). Although morphology, seepage intensity, and composition of seep fluids vary considerably between known submarine MVs, most of them show a concentric pattern in the distribution of chemosynthetic habitats, explained by the presence of one major central chimney for gas, fluid, and mud transport (Olu et al., 1997; Kopf, 2002; Niemann et al., 2006; Dupré et al., 2007, 2008; Huguen et al., 2009; Sommer et al., 2009). Here we found evidence that other than the known limitation of microbial hydrocarbon degradation by rapidly rising sulfate-depleted subsurface fluids (de Beer et al., 2006; Niemann et al., 2006; Joye et al., 2009), the disturbance caused by eruptions of hot subsurface muds and degassing events may cause an intermediate repression of anaerobic hydrocarbon degradation. At Amon MV, subsurface temperatures are high enough to heat-sterilize functionally relevant microbial communities such as anaerobic methanotrophs (Holler et al., 2011). As a result, large quantities of methane and higher hydrocarbons can escape to the water column (Mastalerz et al., 2007, 2009). We observed that due to the slow growth of hydrocarbon-degrading communities, it may take a few years before a benthic filter for methane and other hydrocarbons is developed. Hence, the geological dynamics of MVs can have a substantial influence on the efficiency of microbial communities in controlling hydrocarbon emissions.

\section{Supplementary material related to this article is available online at: http://www.biogeosciences.net/10/ 3269/2013/bg-10-3269-2013-supplement.pdf.}

Acknowledgements. We thank the members of the shipboard crew of the RV Meteor and RV M. S. Merian, as well as the ROV Quest 4000 team (MARUM, Bremen) and the scientific parties for the excellent support with work at sea during the M70-2 Bionil cruise and the MSM13 3/4 expedition. We are grateful for the technical support from Martina Alisch, Viola Beier, Gabriele Schüßler, and Tomas Wilkop, and thank Gabriele Eickert, Ines Schröder, Vera Hübner, Karin Hohmann, Ingrid Dohrmann, and Cecilia Wiegand for the building of microsensors. Special thanks to Volker Asendorf, Patrick Meyer, Axel Nordhausen, and Marc Viehweger for the construction and maintenance of in situ devices as well as for help with work at sea. We thank our colleague Stefanie Meyer for providing the sampling maps. This work contributed to the goals of the ESF EUROCORES EUROMARGIN project Mediflux supported by the German Research Foundation (DFG), CNRS, NWO, the EU FP6 project HERMES (GOCE-CT-2005-511234-1), the EU FP7 project HERMIONE (contract no. 226354), and the GEOTECHNOLOGIEN project MUMM II (03G0608C) funded by the German Ministry of Education and Research (BMBF) as well as the Max Planck Society.

The service charges for this open access publication have been covered by the Max Planck Society.

Edited by: R. Danovaro

\section{References}

Abed-Navandi, D. and Dworschak P. C.: Food sources of tropical thalassinidean shrimps: a stable-isotope study, Mar. Ecol.-Prog. Ser., 291, 159-168, 2005.

Amano, K. and Kiel S.: Fossil vesicomyid bivalves from the North Pacific region, Veliger, 49, 270-293, 2007.

Boetius, A.: Hotspot microbial ecosystem research in the Eastern Mediterranean: fluid flow, transport processes and community structure at cold seeps, 2012.

Boetius, A. and Lochte K.: Effect of organic enrichments on hydrolytic potentials and growth of bacteria in deep-sea sediments, Mar. Ecol.-Prog. Ser., 140, 239-250, 1996.

Boetius, A., Ravenschlag K., Schubert C. J., Rickert D., Widdel F., Gieseke A., Amann R., Jørgensen B. B., Witte U., and Pfannkuche O.: A marine microbial consortium apparently mediating anaerobic oxidation of methane, Nature, 407, 623-626, 2000.

Brazelton, W. J., Schrenk M. O., Kelley D. S., and Baross J. A.: Methane- and sulfur-metabolizing microbial communities dominate the Lost City hydrothermal field ecosystem, Appl. Environ. Microbiol., 72, 6257-6270, 2006.

Brazelton, W. J., Ludwig K. A., Sogin M. L., Andreishcheva E. N., Kelley D. S., Shen C.-C., Edwards R. L., and Baross J. A.: Archaea and bacteria with surprising microdiversity show shifts in dominance over 1000-year time scales in hydrothermal chimneys, PNAS, 107, 1612-1617, doi:10.1073/pnas.0905369107, 2010.

Cline, J. D.: Spectrophotometric determination of hydrogen sulfide in natural waters, Limnol. Oceanogr., 14, 454-458, 1969.

Cordes, E. E., Cunha M. R., Galeron J., Mora C., Olu-Le Roy K., Sibuet M., Van Gaever S., Vanreusel A., and Levin L. A.: The influence of geological, geochemical, and biogenic habitat heterogeneity on seep biodiversity, Mar. Ecol.-Evol. Persp., 31, 51-65, 2010.

de Beer, D., Sauter E., Niemann H., Kaul N., Foucher J. P., Witte U., Schlüter M., and Boetius A.: In situ fluxes and zonation of microbial activity in surface sediments of the Håkon Mosby mud volcano, Limnol. Oceanogr., 51, 1315-1331, 2006.

de Lange, G. and Krijgsman W.: Messinian salinity crisis: A novel unifying shallow gypsum/deep dolomite formation mechanism, Mar. Geology, 275, 273-277, doi:10.1016/j.margeo.2010.05.003, 2010.

de Lange, G. J., Cranston R. E., Hydes D. H., and Boust D.: Extraction of pore water from marine-sediments - a review of possible artifacts with pertinent examples from the North-Atlantic, Mar. Geology, 109, 53-76, 1992.

Dolson, J. C., Boucher P. J., Dodd T., and Ismail J.: Petroleum potential of an emerging giant gas province, Nile Delta and Mediterranean Sea off Egypt, Oil Gas J., 100, 32-37, 2002.

Dubilier, N., Bergin C., and Lott C.: Symbiotic diversity in marine animals: the art of harnessing chemosynthesis, Nat. Rev. Microbiol., 6, 725-740, 2008.

Duperron, S., de Beer D., Zbinden M., Boetius A., Schipani V., Kahil N., and Gaill F.: Molecular characterization of bacteria associated with the trophosome and the tube of Lamellibrachia sp., a siboglinid annelid from cold seeps in the eastern Mediterranean, FEMS Microbiol. Ecol., 69, 395-409, 2009.

Dupré, S., Woodside J., Foucher J. P., de Lange G., Mascle J., Boetius A., Mastalerz V., Stadnitskaia A., Ondreas H., Huguen 
C., Harmegnies F. O., Gontharet S., Loncke L., Deville E., Niemann H., Omoregie E., Roy K. O. L., Fiala-Medioni A., Dahlmann A., Caprais J. C., Prinzhofer A., Sibuet M., Pierre C., Damste J. S. S., and Party N. S.: Seafloor geological studies above active gas chimneys off Egypt (Central Nile Deep Sea Fan), Deep-Sea Res. I, 54, 1146-1172, 2007.

Dupré, S., Buffet G., Mascle J., Foucher J. P., Gauger S., Boetius A., Marfia C., Team A. A., Team Q. R., and Party B. S.: Highresolution mapping of large gas emitting mud volcanoes on the Egyptian continental margin (Nile Deep Sea Fan) by AUV surveys, Mar. Geophys. Res., 29, 275-290, 2008.

Dupré, S., Woodside J., Klaucke I., Mascle J., and Foucher J. P.: Widespread active seepage activity on the Nile Deep Sea Fan (offshore Egypt) revealed by high-definition geophysical imagery, Mar. Geology, 275, 1-19, 2010.

Dworschak, P. C.: The burrows of Callianassa tyrrhena (Petagna 1792) (Decapoda : Thalassinidea), Marine EcologyPubblicazioni Della Stazione Zoologica Di Napoli I, 22, 155-166, 2001.

Felden, J., Wenzhöfer F., Feseker T., and Boetius A.: Transport and consumption of oxygen and methane in different habitats of the Håkon Mosby Mud Volcano (HMMV), Limnol. Oceanogr., 55, 2366-2380, 2010.

Feseker, T., Foucher J. P., and Harmegnies F.: Fluid flow or mud eruptions? Sediment temperature distributions on Håkon Mosby mud volcano, SW Barents Sea slope, Mar. Geology, 247, 194207, 2008.

Foucher, J. P., Westbrook G. K., Boetius A., Ceramicola S., Dupre S., Mascle J., Mienert J., Pfannkuche O., Pierre C., and Praeg D.: Structure and drivers of cold seep ecosystems, Oceanography, 22, 92-109, 2009.

Freiwald, A., Boetius A., Bohrmann G., and Forschungsschiffe L. D.: METEOR-Berichte 11-5; Deep water ecosystems of the Eastern Mediterranean; Cruise No. 70, Leg 1-3 Institut für Meereskunde der Universität Hamburg, Hamburg, 2011.

Girnth, A. C., Grunke S., Lichtschlag A., Felden J., Knittel K., Wenzhöfer F., de Beer D., and Boetius A.: A novel, mat-forming Thiomargarita population associated with a sulfidic fluid flow from a deep-sea mud volcano, Environ. Microbiol., 13, 495-505, doi:10.1111/j.1462-2920.2010.02353.x, 2011.

Grünke, S., Felden J., Lichtschlag A., Girnth A. C., de Beer D., Wenzhöfer F., and Boetius A.: Niche differentiation among matforming, sulfide-oxidizing bacteria at cold seeps of the Nile Deep Sea Fan (Eastern Mediterranean Sea), Geobiology, 9, 330-348, 2011.

Hall, P. O. and Aller R. C.: Rapid, small-volume, flow-Injection analysis for Sigma- $\mathrm{CO}_{2}$ and $\mathrm{NH}_{4}^{+}$in marine and fresh-waters, Limnol. Oceanogr., 37, 1113-1119, 1992.

Holler, T., Widdel F., Knittel K., Amann R., Kellermann M. Y., Hinrichs K.-U., Teske A., Boetius A., and Wegner G.: Thermophilic anaerobic oxidation of methane by marine microbial consortia, ISME J., 5, 1946-1956, doi:10.1038/ismej.2011.77, 2011.

Huguen, C., Foucher J. P., Mascle J., Ondreas H., Thouement M., Gontharet S., Stadnitskaia A., Pierre C., Bayon G., Loncke L., Boetius A., Bouloubassi I., de Lange G., Caprais J. C., Fouquet Y., Woodside J., Dupre S., and Party N. S.: Menes caldera, a highly active site of brine seepage in the Eastern Mediterranean sea: In situ observations from the NAUTINIL expedition (2003), Mar. Geology, 261, 138-152, 2009.
Inagaki, F., Kuypers M. M. M., Tsunogai U., Ishibashi J., Nakamura K., Treude T., Ohkubo S., Nakaseama M., Gena K., Chiba H., Hirayama H., Nunoura T., Takai K., Jorgensen B. B., Horikoshi K., and Boetius A.: Microbial community in a sediment-hosted $\mathrm{CO}_{2}$ lake of the southern Okinawa Trough hydrothermal system, Proc. Natl. Acad. Sci. USA, 103, 14164-14169, 2006.

Jeroschewski, P., Steuckart C., and Kuhl M.: An amperometric microsensor for the determination of $\mathrm{H}_{2} \mathrm{~S}$ in aquatic environments, Anal. Chem., 68, 4351-4357, 1996.

Jørgensen, B. B.: A comparison of methods for the quantification of bacterial sulfate reduction in coastal marine sediments, I. Measurements with radiotracer techniques, Geomicrobiol. J., 1, 1127, 1978.

Jørgensen, B. B. and Boetius A.: Feast and famine - microbial life in the deep-sea bed, Nat. Rev. Microbiol., 5, 770-781, 2007.

Joye, S. B., Boetius A., Orcutt B. N., Montoya J. P., Schulz H. N., Erickson M. J., and Lugo S. K.: The anaerobic oxidation of methane and sulfate reduction in sediments from Gulf of Mexico cold seeps, Chem. Geol., 205, 219-238, 2004.

Joye, S. B., Samarkin V., B. O., Macdonald I. R., Hinrichs K.-U., Elvert M., Teske A., Lloyd K. G., Lever M. A., Montoya J. P., and Meile C. D.: Metabolic variability in seafloor brines revealed by carbon and sulphur dynamics, Nature Geosci., 2, 349-354, doi:10.1038/NGEO475, 2009.

Kallmeyer, J. and Boetius A.: Effects of temperature and pressure on sulfate reduction and anaerobic oxidation of methane in hydrothermal sediments of Guaymas Basin, Appl. Environ. Microbiol., 70, 1231-1233, 2004.

Kallmeyer, J., Ferdelman T. G., Weber A., Fossing H., and Jørgensen B. B.: A cold chromium distillation procedure for radiolabeled sulfide applied to sulfate reduction measurements, Limnol. Oceanogr. Methods, 2, 171-180, 2004.

Knittel, K. and Boetius A.: Anaerobic oxidation of methane: progress with an unknown process, Annu. Rev. Microbiol., 63, 311-314, 2009.

Kopf, A. J.: Significance of mud volcanism, Rev. Geophys., 40, 145, 2002.

Lichtschlag, A., Felden J., Brüchert V., Boetius A., and de Beer D.: Geochemical processes and chemosynthetic primary production in different thiotrophic mats of the Håkon Mosby Mud Volcano (Barents Sea), Limnol. Oceanogr., 55, 931-949, 2010a.

Lichtschlag, A., Felden J., Wenzhöfer F., Schubotz F., Ertefai T. F., Boetius A., and de Beer D.: Methane and sulfide fluxes in permanent anoxia: In situ studies at the Dvurechenskii mud volcano (Sorokin Trough, Black Sea), Geochim. Cosmochim. Acta, 74, 5002-5018, 2010b.

Lustwerk, R. L. and Burdige D. J.: Elimination of dissolved sulfide interference in the flow injection determination of $\mathrm{CO}_{2}$, by addition of molybdate, Limnol. Oceanogr., 40, 1011-1012, 1995.

Mascle, J., Zitter T., Bellaiche G., Droz L., Gaullier V., Loncke L., and Party P. S.: The Nile deep sea fan: preliminary results from a swath bathymetry survey, Mar. Petrol. Geol., 18, 471-477, 2001.

Mascle, J., Sardou O., Loncke L., Migeon S., Camera L., and Gaullier V.: Morphostructure of the Egyptian continental margin: Insights from swath bathymetry surveys, Mar. Geophys. Res., 27, 49-59, 2006.

Mastalerz, V., de Lange G. J., Dahlmann A., and Feseker T.: Active venting at the Isis mud volcano, offshore Egypt: origin and migration of hydrocarbons, Chem. Geol., 246, 87-106, 2007. 
Mastalerz, V., de Lange G. J., and Dahlmann A.: Differential aerobic and anaerobic oxidation of hydrocarbon gases discharged at mud volcanoes in the Nile deep-sea fan, Geochim. Cosmochim. Acta, 73, 3849-3863, 2009.

Meyer-Reil, L. A.: Benthic response to sedimentation events during autumn to spring at a shallow water station in the Western Kiel Bight, Mar. Biol., 77, 247-256, 1983.

Milkov, A. V.: Worldwide distribution of submarine mud volcanoes and associated gas hydrates, Mar. Geology, 167, 29-42, 2000.

Nauhaus, K., Albrecht M., Elvert M., Boetius A., and Widdel F.: In vitro cell growth of marine archaeal-bacterial consortia during anaerobic oxidation of methane with sulfate, Environ. Microbiol., 9, 187-196, 2007.

Niemann, H., Lösekann T., de Beer D., Elvert M., Nadalig T., Knittel K., Amann R., Sauter E. J., Schluter M., Klages M., Foucher J. P., and Boetius A.: Novel microbial communities of the Håkon Mosby mud volcano and their role as a methane sink, Nature, 443, 854-858, 2006.

Olu, K., Lance S., Sibuet M., Henry P., Fialamedioni A., and Dinet A.: Cold seep communities as indicators of fluid expulsion patterns through mud volcanoes seaward of the Barbados accretionary prism, Deep-Sea Res. I, 44, 811-841, 1997.

Omoregie, E. O., Mastalerz V., de Lange G., Straub K. L., Kappler A., Roy H., Stadnitskaia A., Foucher J. P., and Boetius A.: Biogeochemistry and community composition of iron- and sulfurprecipitating microbial mats at the Chefren mud volcano (Nile Deep Sea fan, Eastern Mediterranean), Appl. Environ. Microbiol., 74, 3198-3215, 2008.

Omoregie, E. O., Niemann H., Mastalerz V., de Lange G. J., Stadnitskaia A., Mascle J., Foucher J. P., and Boetius A.: Microbial methane oxidation and sulfate reduction at cold seeps of the deep Eastern Mediterranean Sea, Mar. Geology, 261, 114-127, 2009.

Reeburgh, W. S.: Oceanic methane biogeochemistry, Chem. Rev., 107, 486-513, 2007.

Revsbech, N. P. and Ward D. M.: Oxygen microelectrode that is insensitive to medium chemical-composition - use in an acid microbial mat dominated by cyanidium-caldarium, Appl. Environ. Microbiol., 45, 755-759, 1983.

Revsbech, N. P., Jørgensen B. B., Blackburn T. H., and Cohen Y.: Microelectrode studies of the photosynthesis and $\mathrm{O}_{2}, \mathrm{H}_{2} \mathrm{~S}$, and pH profiles of a microbial mat, Limnol. Oceanogr., 28, 10621074, 1983.

Ritt, B., Pierre C., Gauthier O., Wenzhöfer F., Boetius A., and Sarrazin J.: Diversity and distribution of cold-seep fauna associated with different geological and environmental settings at mud volcanoes and pockmarks of the Nile Deep-Sea Fan, Mar. Biol., 158, 1187-1210, doi:10.1007/s00227-011-1679-6, 2011.
Schouten, S., Wakeham S. G., Hopmans E. C., and Damste J. S. S.: Biogeochemical evidence that thermophilic archaea mediate the anaerobic oxidation of methane, Appl. Environ. Microbiol., 69, 1680-1686, 2003.

Sibuet, M. and Olu K.: Biogeography, biodiversity and fluid dependence of deep-sea cold-seep communities at active and passive margins, Deep-Sea Res. II, 45, 517-567, 1998.

Sommer, S., Linke P., Pfannkuche O., Schleicher T., Schneider V.Deimling J., Reitz A., Haeckel M., Flögel S., and Hensen C.: Seabed methane emssion and the habitat of frenulate tubrworms on the Captain Arutyunov mud volcano (Gulf of Cadiz), Mar. Ecol.-Prog. Ser., 382, 69-86, 2009.

Teske, A., Hinrichs K. U., Edgcomb V., Gomez A. D., Kysela D., Sylva S. P., Sogin M. L., and Jannasch H. W.: Microbial diversity of hydrothermal sediments in the Guaymas Basin: Evidence for anaerobic methanotrophic communities, Appl. Environ. Microbiol., 68, 1994-2007, 2002.

Treude, T., Boetius A., Knittel K., Wallmann K., and Jørgensen B. B.: Anaerobic oxidation of methane above gas hydrates at Hydrate Ridge, NE Pacific Ocean, Mar. Ecol.-Prog. Ser., 264, 1-14, 2003.

Villinger, H. and Davis E. E.: A new reduction algorithm for marine heat flow measurements, J. Geophys. Res., 92, 12846-12856, doi:10.1029/JB092iB12p12846, 1987.

Wenzhöfer, F., Holby O., Glud R. N., Nielsen H. K., and Gundersen J. K.: In situ microsensor studies of a shallow water hydrothermal vent at Milos, Greece, Mar. Chem., 69, 43-54, 2000.

Werne, J. P., Haese R. R., Zitter T., Aloisi G., Bouloubassi L., Heijs S., Fiala-Medioni A., Pancost R. D., Damste J. S. S., de Lange G., Forney L. J., Gottschal J. C., Foucher J. P., Mascle J., Woodside J., and Pa M. M. S. S.: Life at cold seeps: a synthesis of biogeochemical and ecological data from Kazan mud volcano, eastern Mediterranean Sea, Chem. Geol., 205, 367-390, 2004.

Widdel, F. and Bak F.: Gram-negative mesophilic sulfate-reducing bacteria, in: The Prokaryotes, 2 Edn., edited by: Balows, A., Trüper, H. G., Dworkin, M., Harder, W., and Schleifer, K.-H., Springer-Verlag, New York, 3352-3378, 1992.

Yamamoto, S., Alcauskas J. B., and Crozier T. E.: Solubility of methane in distilled water and seawater, J. Chem. Eng. Data, 21, 78-80, 1976.

Yanagawa, K., Morono Y., Debeer D., Haeckel M., Sunamura M., Futagami T., Hoshino T., Terada T., Nakamura K.-I., Urabe T., Rehder G., Boetius A., and Inagaki F.: Metabolically active microbial communities in marine sediment under high- $\mathrm{CO}_{2}$ and low-pH extremes, ISME J., 1-13, doi:10.1038/ismej.2012.124, 2012.

Ziebis, W., Forster S., Huettel M., and Jørgensen B. B.: Complex burrows of the mud shrimp Callianassa truncata and their geochemical impact in the sea bed, Nature, 383, 457-457, 1996. 